Katarzyna Liczmańska

\title{
PROMOCJA KONSUMENCKA W WARUNKACH ZAKAZU REKLAMY PUBLICZNEJ
}

Z a r y s tre ś c i. W dzisiejszej rzeczywistości gospodarczej, kiedy główną siłą ekonomiczną jest hiperkonkurencja, kluczowym celem funkcjonowania przedsiębiorstw staje się zadowolenie klienta. Przedsiębiorstwo, aby sprawnie funkcjonować, musi prowadzić na szeroką skalę działania promocyjne, mające na celu aktywizację sprzedaży. W sektorze alkoholi wysokoprocentowych poważnym utrudnieniem w komunikacji marketingowej stają się restrykcje państwa zakazujące działań reklamowych. Autorka artykułu stawia tezę, że w obliczu całkowitego zakazu reklamy publicznej nadal można oddziaływać na decyzje zakupowe i aktywizować sprzedaż.

Słow a kluczowe: promocja konsumencka, komunikacja, reklama.

\section{WSTEP}

Głównym celem marketingu jest zaspokojenie potrzeb konsumentów (Germain 2006, s. 29), a w centrum wszechświata marketingu znajduje się klient (Kotler 2004, s. 18). Postęp cywilizacyjny i technologiczny zmusza przedsiębiorstwa do funkcjonowania w rzeczywistości gospodarczej, kreowanej nasiloną konkurencją (Haffer, 1998, s. 30). Aby utrzymać pozycję konkurencyjną i wygrywać w walce o klienta, należy go zadowolić, a do tego niezbędna staje się skuteczna komunikacja marketingowa.

Jednym z najskuteczniejszych instrumentów marketing-mix jest reklama publiczna. Sektor alkoholi wysokoprocentowych charakteryzuje się specyficznymi ograniczeniami, utrudniającymi komunikację skierowaną do konsumenta przez całkowity zakaz reklamy publicznej. 
Jednym z poważniejszych wyzwań, przed jakim stoją przedsiębiorstwa funkcjonujące w omawianym sektorze, jest prowadzenie komunikacji marketingowej uwzględniającej restrykcje państwa wobec reklamy publicznej. Autorka artykułu stawia tezę, że w obliczu całkowitego zakazu reklamy publicznej nadal można oddziaływać na decyzje zakupowe i aktywizować sprzedaż ${ }^{1}$.

\section{INSTRUMENTY PROMOCJI KONSUMENCKIEJ PODSTAWY TEORETYCZNE}

Kluczowym zadaniem przedsiębiorstw jest dostarczanie na rynek produktów, których konsumpcja zadowala nabywców i które równocześnie przynoszą maksimum korzyści ekonomicznych (Kotler 1999, s. 16). Zadaniu temu podporządkowana jest wszelka działalność firmy. Aby w pełni je realizować, niezbędne jest nawiązanie komunikacji z pozostałymi uczestnikami rynku. Działania komunikacyjne, jakie w tym celu stosuje przedsiębiorstwo, są następujące:

- reklama, czyli płatna, bezosobowa forma rozpowszechniania informacji o towarach, firmach, której celem jest oddziaływanie perswazyjne na odbiorcę (Kozłowska, 2011, s. 44-46);

- promocja sprzedaży, czyli stosowanie dodatkowych zachęt dla konsumentów, mających zwiększyć atrakcyjność produktu (Mazurek-Łopacińska, 2003, s. 161);

- public relations, czyli działania polegające na kształtowaniu pozytywnych relacji firmy z jej otoczeniem w celu zwiększenia zaufania do przedsiębiorstwa (Pawlak-Kołodziejska, 2011, s. 309);

- promocja osobista, czyli osobista prezentacja towarów, mająca na celu doprowadzenie do ich zakupu.

Przedstawione instrumenty komunikacyjne stanowią zespół sprzężonych ze sobą środków, dzięki którym przedsiębiorstwo osiąga swoje cele marketingowe (Kozłowska, 2011, s. 54). Wykorzystanie poszczególnych środków promocji zależy od wielu czynników. W sektorze alkoholi wysokoprocentowych główne ograniczenie stanowi całkowity zakaz reklamy oraz wszelkich instrumentów komunikacji masowej. Ze względu na przedstawione restrykcje autorka artykułu

1 W artykule przedstawiono wyniki dwóch uzupełniających się badań. Pierwsze zostało zrealizowane metodą wywiadu osobistego na próbie 1500 respondentów indywidualnych w Polsce w roku 2007, natomiast drugie przeprowadzono metodą ankiety bezpośredniej lub internetowej na próbie 16 przedsiębiorstw produkujących bądź importujących alkohole wysokoprocentowe. Stanowią one grupę, która ma w swojej ofercie najbardziej znane i liczące się marki alkoholi, łącznie odpowiadają za $95,95 \%$ rynku. 
skupia się na działaniach z zakresu promocji sprzedaży prowadzonych zgodnie z obowiązującym prawem.

W literaturze przedmiotu można znaleźć dwa zupełnie rozbieżne podejścia do promocji sprzedaży. Krytycy argumentują (Ehrenberg, Hammond, Goodhardt 1994, s.13-14), iż konsumenci podatni na promocję sprzedaży nie są lojalni, co powoduje straty w dłuższej perspektywie. Zwolennicy natomiast wykazują, że promocja sprzedaży może prowadzić do rzeczywistego długotrwałego wzrostu sprzedaży i zysków (Dhar, Hoch, 1996, s. 17-18). Promocja sprzedaży dostarcza wielu korzyści, które są ważne zarówno dla gestora marki, jak i konsumentów (Witek-Hajduk, red., 2011, s. 185).

Promocja sprzedaży nastawiona jest w głównej mierze na krótkookresowe działanie w celu pobudzenia sprzedaży produktu przez różnego rodzaju instrumenty (Kotler 1999, s. 546). Kluczowym jej zadaniem jest wzbudzanie u nabywcy przekonania, że zyskuje coś więcej niż wyłącznie produkt w dobrej cenie (Cummins, Mullin, 2005, s. 49). Promocja sprzedaży może być skierowana do pośredników handlowych - promocja handlowa, bądź ostatecznych nabywców - promocja konsumencka. Wśród podstawowych form promocji konsumenckiej można wymienić (Cummins, Mullin 2005, s. 49; Wiktor 2005, s. 199-202; Kozłowska 2011, s. 46;): promocje cenowe (kupony, obniżki cen, rabaty), promocje z upominkiem, próbki, degustacje, konkursy, kupony, prospekty oraz merchandising.

\section{UWARUNKOWANIA KOMUNIKACJI MARKETINGOWEJ W SEKTORZE ALKOHOLI WYSOKOPROCENTOWYCH}

Sektor alkoholi wysokoprocentowych w Polsce objęty jest całkowitym zakazem reklamy publicznej. Podstawowym aktem ograniczającym reklamę napojów alkoholowych jest Ustawa z dnia 26 października 1982 r. o wychowaniu w trzeźwości i przeciwdziałaniu alkoholizmowi. Możliwości komunikacji z konsumentem są poważnie ograniczone dla producentów alkoholi mocnych, mają oni zatem poważny problem i trudne zadanie. Główny trunek w kategorii alkoholi wysokoprocentowych w Polsce to wódki czyste, mocno upraszczając, a zawartość każdej butelki wódki to spirytus i woda. Wobec czego dostępne marki w niewielkim stopniu mogą różnić się smakiem. W tej sytuacji producent musi dotrzeć do konsumenta z informacją, by przekonać go, aby to właśnie oferowany przez niego produkt wybrał. Zakaz reklamy, a tym samym utrudnienia w tworzeniu komunikatów promocyjnych zmuszają producentów alkoholi do szukania nowych możliwości, tworzenia trunków takich, by wyróżniały się i zdobywały uznanie konsumentów wśród szerokiej oferty dostępnych produktów konkurencyjnych. 
Pojęcie promocji napojów alkoholowych jest bardzo szerokie i oznacza publiczną degustację napojów alkoholowych, rozdawanie rekwizytów, organizowanie premiowanej sprzedaży, a także inne formy publicznego zachęcania do nabywania napojów alkoholowych. Natomiast reklama to publiczne rozpowszechnianie znaków towarowych napojów alkoholowych lub symboli graficznych z nimi związanych, a także nazw i symboli graficznych przedsiębiorstw produkujących napoje alkoholowe, nieróżniących się od nazw i symboli graficznych napojów alkoholowych, służące popularyzowaniu znaków towarowych napojów alkoholowych. Mimo znacznych ograniczeń w zakresie reklamy alkoholu, w sklepach jej stosowanie jest możliwe, jednak działania promocyjne muszą być prowadzone zgodnie z prawem, tzn. z wykorzystaniem tylko legalnych form marketingu.

Wszelkie badania dotyczące struktury spożycia alkoholi w Polsce prymat przyznają trunkom mocnym z wódką na czele, które walczą o palmę pierwszeństwa ze zdecydowanie bardziej sezonowym produktem, jakim jest piwo, amatorom wina pozostaje $8-10 \%$ rynku. To właśnie wódka cieszy się w naszym kraju szczególną popularnością wśród konsumentów

\section{FORMY PROMOCJI KONSUMENCKIEJ STOSOWANE W SEKTORZE ALKOHOLI WYSOKOPROCENTOWYCH}

Tradycyjna reklama to kluczowa zmienna w marketingu-mix (Kotler, 2004, s. 93). Jednak w sytuacji, gdy reklama publiczna jest zakazana, nasilają się działania z zakresu promocji sprzedaży. Poniżej znajduje się wykres obrazujący formy promocji skierowane do konsumenta finalnego, stosowane przez producentów sektora alkoholi wysokoprocentowych (w deklaracjach producentów).

Największą popularnością wśród form promocji skierowanych do konsumenta finalnego cieszą się merchandising oraz promocje cenowe, stosują je wszyscy producenci. Nieco mniej przedsiębiorców oferuje konsumentom promocje z gratisem. Plakaty i wywieszki informacyjne w miejscach sprzedaży umieszcza $64 \%$ ankietowanych. Na kolejnych pozycjach znajdują się działania w internecie oraz rozszerzanie marki na inne produkty. Blisko połowa ankietowanych proponuje odbiorcy okazjonalne opakowania, jak również organizuje promocje z hostessą. Zdecydowanie mniejszą popularnością wśród działań skierowanych bezpośrednio do konsumenta cieszą się: eventy, PR, konkursy, degustacje, programy lojalnościowe (wykres 1).

W trakcie prowadzonych badań ankietowano również konsumentów, ich deklaracje dotyczące działań promocyjnych, które zauważają, przedstawia wykres 2. 


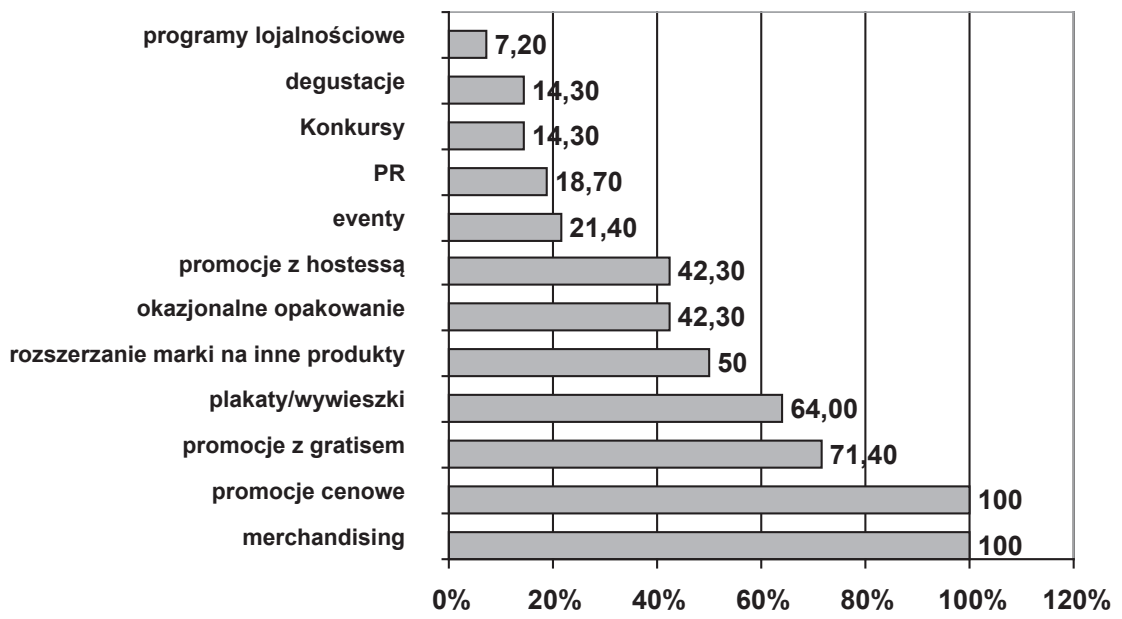

Wykres 1. Formy promocji stosowane w sektorze alkoholi wysokoprocentowych Źródło: opracowanie własne na podstawie przeprowadzonych badań.

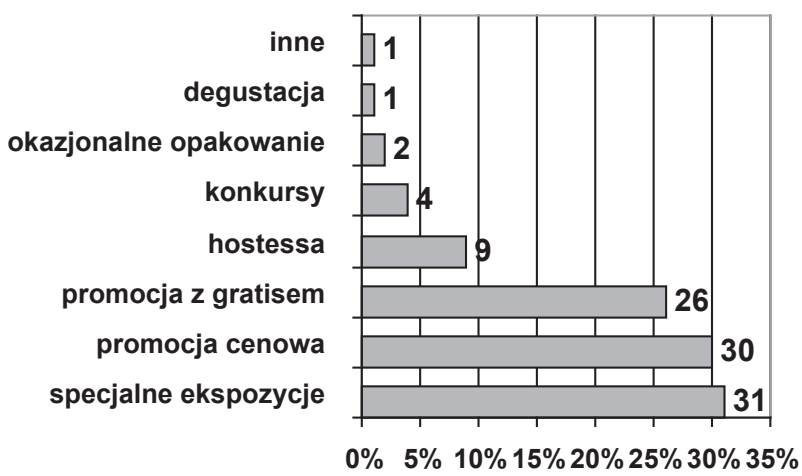

Wykres 2. Rozkład deklaracji konsumentów dotyczących rodzajów działań promocyjnych producentów alkoholi wysokoprocentowych zauważanych przez konsumentów

Źródło: opracowanie własne na podstawie przeprowadzonych badań.

Największy odsetek kupujących zauważa działania z zakresu merchandisingu, takie jak: specjalne ekspozycje półkowe, listwy, odpowiednie rozlokowanie produktów w sklepie oraz całość działań realizowanych przez producentów w punkcie sprzedaży. Na kolejnej pozycji, ze wskazaniami $30 \%$, uplasowały się promocje cenowe. Cena może działać na korzyść wyboru danej marki - jeśli jest niska, może również zmniejszać prawdopodobieństwo jej zakupu - jeśli jest wysoka (Alvarez, Casielles, 2005, s. 67-68). Niewiele mniej badanych obserwuje 
wszelkie promocje z gratisem, kiedy to do butelek dokładane są różnego rodzaju upominki. Na kolejnych miejscach, z niższymi wskazaniami, znalazły się sporadycznie dostrzegane promocje z hostessą, konkursy, okazjonalne opakowania, degustacje.

\section{SKUTECZNOŚĆ PROMOCJI KONSUMENCKIEJ W SEKTORZE ALKOHOLI WYSOKOPROCENTOWYCH}

Proces kupowania poprzedza zbieranie informacji, w tym celu konsument czerpie zarówno ze źródeł zewnętrznych: reklama, informacje w punkcie sprzedaży, PR, jak i ze źródeł wewnętrznych, takich jak pamięć (Wiśniewska, 2005, s. 14-16). Proces zakupu wódki jest zbliżony do zakupu innych produktów konsumpcyjnych, problemem jedynie może być utrudniona komunikacja pomiędzy właścicielem marki a konsumentem. Podczas prowadzonych badań, w celu analizy zachowań konsumenckich, zapytano kupujących alkohole, czy dokonując zakupów, zauważają działania marketingowe wódek. Wyniki przedstawia wykres 3 .

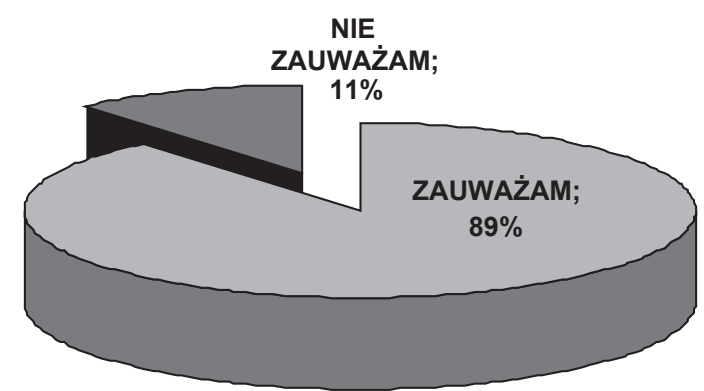

Wykres 3. Rozkład deklaracji konsumentów dotyczących zauważania działań marketingowych

Źródło: opracowanie własne na podstawie przeprowadzonych badań.

$89 \%$ badanych potwierdziło, że zauważa działania marketingowe producentów wódek, zaledwie niewielki procent to odpowiedzi przeczące. Powyższe deklaracje wskazują na wysoką skuteczność komunikacyjną prowadzonych przez producentów działań promocyjnych, lecz trudno jeszcze stwierdzić, jaki wpływ mają one na aktywizację sprzedaży. Konsumenci wypowiedzieli się również na temat tego, jakie promocje wódek są dla nich atrakcyjne (wykres 4). 


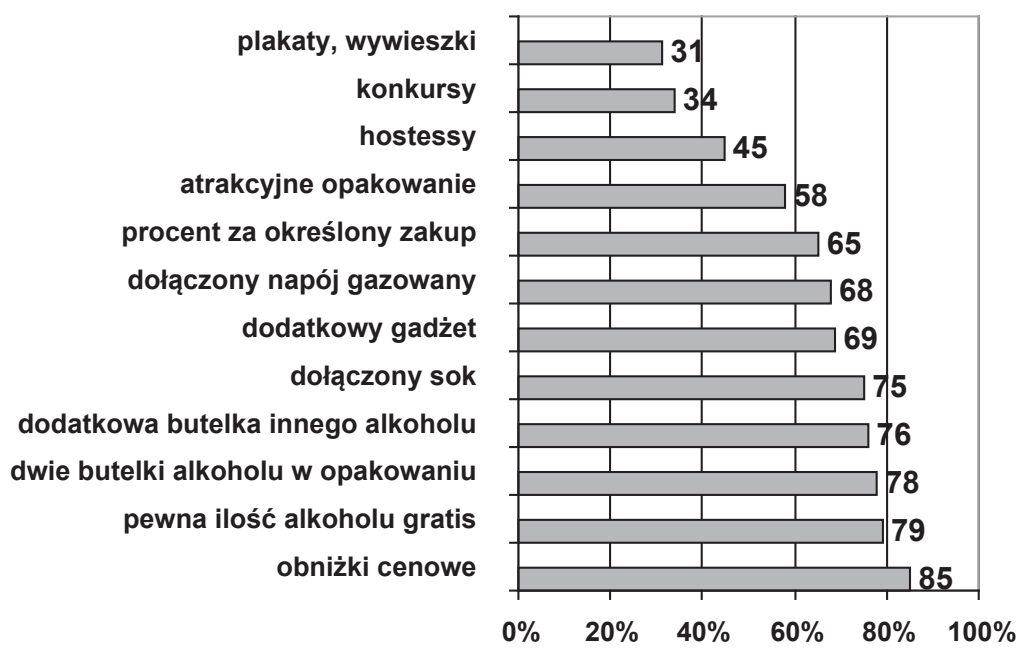

Wykres 4. Atrakcyjność promocji wódek z punktu widzenia konsumenta Źródło: opracowanie własne na podstawie przeprowadzonych badań.

Wśród najbardziej atrakcyjnych promocji klienci planujący zakup wódki wskazali te, które pozwalają otrzymać większą ilość alkoholu w tej samej cenie: obniżki cenowe, pewną ilość produktu gratis czy dwie butelki w opakowaniu. Podobny odsetek konsumentów ceni sobie promocje w formie pewnej ilości alkoholu gratis. Z czynnikiem atrakcyjnej ceny związana jest też kolejna forma promocji: dwie butelki w jednym opakowaniu. Niewiele mniej konsumentów wskazuje na atrakcyjność dodatkowej butelki innego alkoholu w jednym opakowaniu. Wszystkie działania wskazane jako kluczowe świadczą o tym, że konsumenci zdecydowanie chcą otrzymywać większą ilość produktu w tej samej cenie, te promocje są dla nich najbardziej atrakcyjne.

Dołączony sok jest również pożądaną zachętą do zakupu, podobne wskazania uzyskała gratisowa butelka napoju gazowanego. Pozytywnie przez konsumentów zostały również ocenione promocje w postaci dołączonych upominków - gadżetów. Przychylnie konsumenci wypowiadają się też o promocji w formie wynagradzania prezentem zakupów za określoną kwotę.

Konsumenci zwracają również uwagę na atrakcyjne opakowanie wódki, sugeruje tak aż $58 \%$ respondentów. W przypadku tego specyficznego produktu, gdy zawartość butelek jest zbliżona do siebie, rzeczywiście opakowanie odgrywa dużą rolę, tym bardziej że butelka wódki najczęściej stawiana jest na stole w gronie znajomych. 


\section{POWODY WYBORU DANEJ MARKI WÓDKI ORAZ ZMIAN DECYZJI ZAKUPOWYCH}

Przedstawione z przeprowadzonych badań wnioski nie pozostawiają wątpliwości, że w omawianym sektorze producenci korzystają z wszelkich możliwości działań marketingowych, uwzględniając jednak ustawę o wychowaniu w trzeźwości, całkowicie zakazującą reklamy publicznej.

Konsumenci mają swoje preferencje, bardzo duże znaczenie dla wyboru wódki ma silna, znana marka. W dalszej kolejności, analizując wyniki badań, autorka ustaliła, jak wszelkie działania marketingowe prowadzone przez producentów alkoholi wysokoprocentowych wpływają na decyzje zakupowe konsumentów. Klientów, którzy zmienili plany zakupowe, stojąc przed sklepową półką, zapytano o przyczyny zmiany decyzji. Wyniki przedstawia wykres 5 .

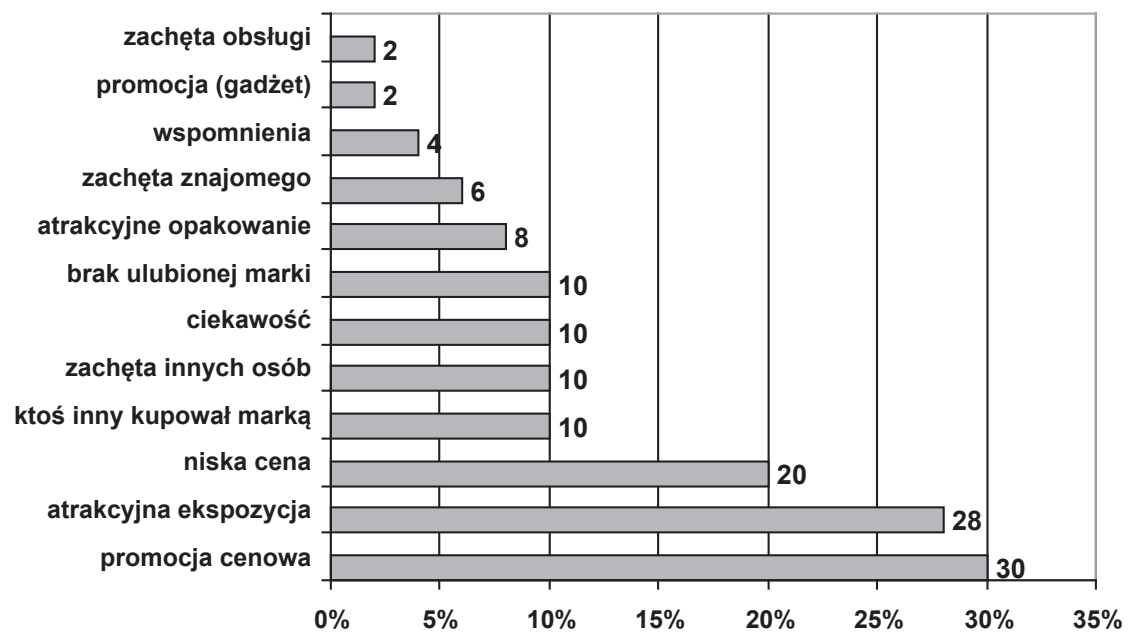

Wykres 5. Powody zmiany decyzji zakupowych przed półką sklepową deklarowane przez konsumentów

Źródło: opracowanie własne na podstawie badań własnych autorki.

Z powyższego wykresu wyraźnie wynika, że kluczowe znaczenie dla tej grupy nabywców miała atrakcyjna promocja cenowa. Działania promocyjne wódek są głównym czynnikiem decydującym o wyborze produktu przed półką sklepową. Jak się okazuje, największe znaczenie mają promocje cenowe. Inne promocje takie, jak gadżet to zaledwie $2 \%$ wskazań. Na drugiej pozycji wśród argumentów decydujących o wyborze marki znajdują się również działania 
z zakresu promocji konsumenckiej, zwracająca uwagę ekspozycja, dzięki której marka jest zauważalna.

W następnej kolejności badani podają niską cenę, co czyni wskaźnik cenowy bardzo ważnym argumentem w procesie decyzji zakupowych podejmowanych przed półką sklepową. Wśród znaczących powodów wymieniane są również: ciekawość, chęć spróbowania czegoś nowego, zachęta innej osoby, brak wybranej wcześniej marki, opakowanie. Z ciekawości, chęci spróbowania czegoś innego kupuje $10 \%$ ankietowanych. Warto pozyskać takiego konsumenta - odkrywcę, ponieważ jeżeli polubi daną markę, jest szansa, że zostanie jej lojalnym konsumentem. Kolejne 10\% zadeklarowanych czynników wpływających na zmianę planów zakupowych to brak wybranej marki na półce, natomiast najmniejsze znaczenie mają takie czynniki jak: polecenie hostessy bądź osoby z obsługi oraz promocja (gadżet).

O czynniki, które wpływają na decyzje zakupowe, zapytano również klientów, którzy nabyli dodatkową markę wódki oprócz planowanej, dokonując wyboru spontanicznie, przed półką sklepową (wykres 6).

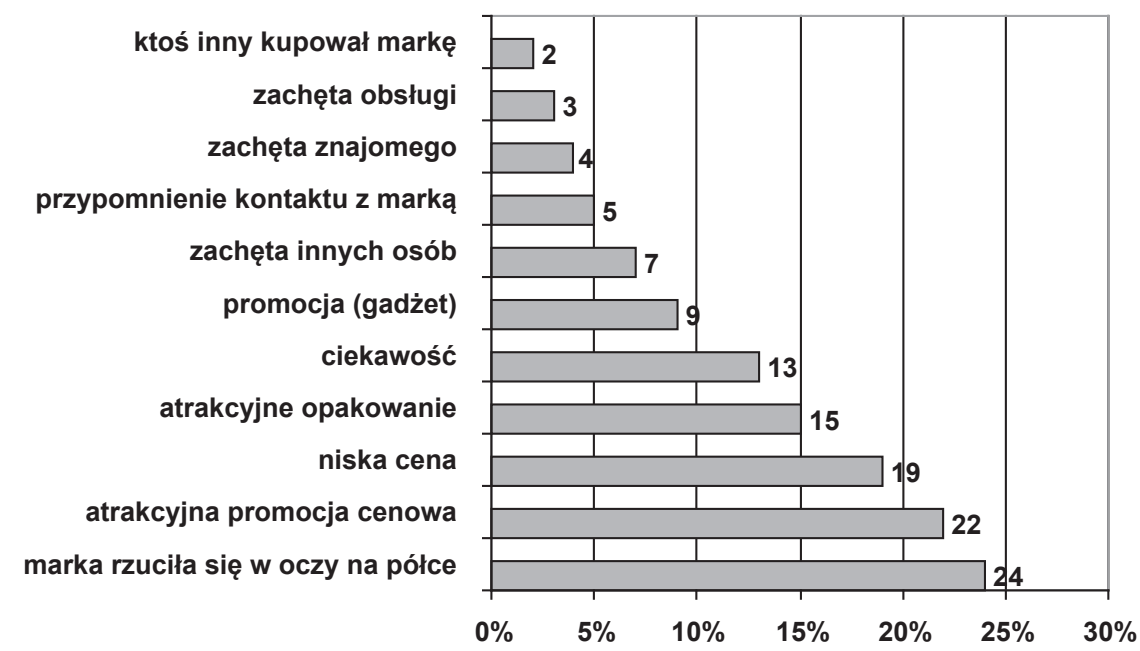

Wykres 6. Powody zakupu dodatkowej marki wódki, oprócz planowanej

Źródło: opracowanie własne na podstawie badań konsumenckich.

Z analizy wykresu wynika, iż dla konsumentów, którzy dokonali dodatkowo zakupu nieplanowanej marki wódki, głównymi powodami takiej decyzji są działania promocyjne. Najważniejszym czynnikiem decydującym o zakupie dodatkowej marki wódki jest odpowiednia ekspozycja. Po raz kolejny zauważyć można, jak ważne dla klientów są działania merchandisingowe. Najczęściej nabywane 
marki, jeżeli decyzje dotyczące ich wyboru zapadały w sklepie, to te, które są doskonale wyeksponowane i nie ma problemu ze znalezieniem ich na półce.

W następnej kolejności badani podają atrakcyjną promocję cenową oraz niską cenę produktu. Można zauważyć, że również dla tej grupy ankietowanych bardzo ważna jest silna, uznana marka, znaczącym czynnikiem jest również niska cena. Na kolejnych miejscach znalazły się czynniki takie jak: interesujące opakowanie oraz chęć spróbowania czegoś nowego. Czynniki określone, jako najmniej ważne to: polecenie hostessy, kogoś z obsługi lub znajomych, jak również widok innych klientów kupujących tę markę.

Na wykresie 7 przedstawione zostało porównanie marek, których promocje klienci zauważyli podczas kupowania już wybranego alkoholu.

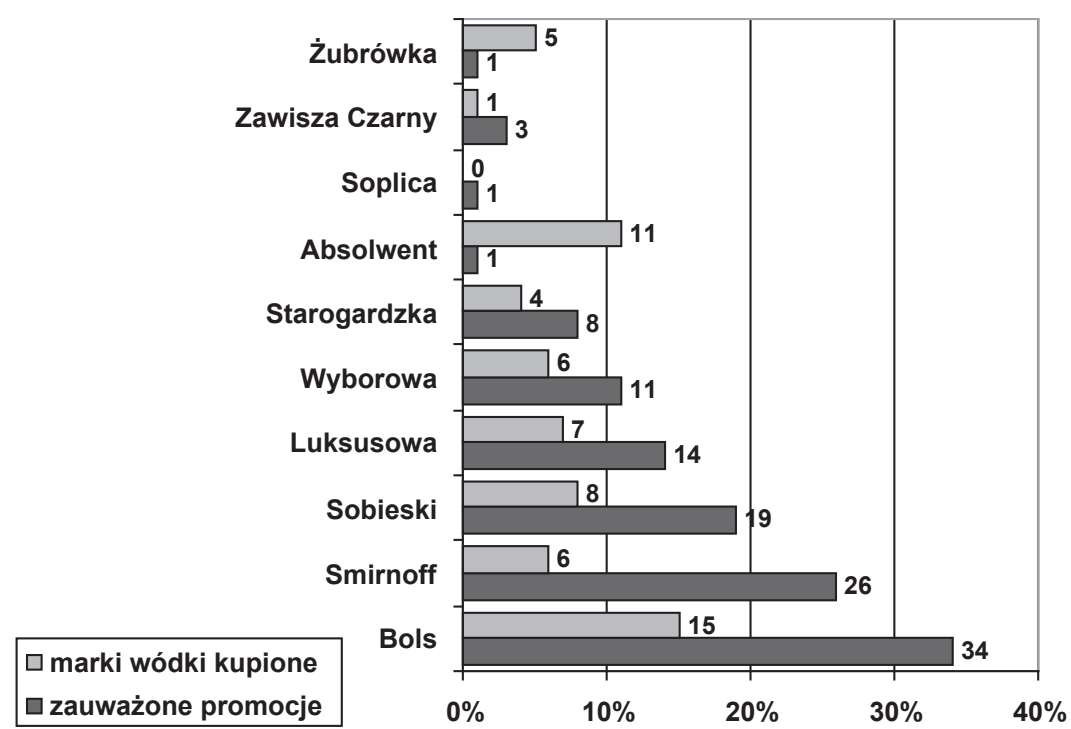

Wykres 7. Porównanie marek, których promocje konsumenci zauważyli, z tymi, które zakupili, dokonując wyboru przed półką sklepową

Źródło: opracowanie własne na podstawie przeprowadzonych badań.

Zarówno w pierwszym, jak i drugim rankingu na pierwszym miejscu znalazła się wódka Bols, czołowe pozycje zajmują również: Sobieski, Luksusowa, Smirnoff, Wyborowa. Na podstawie porównywanych informacji niepodważalnie można stwierdzić, że zasadniczy wpływ na wybór marek wśród klientów, którzy te decyzje podejmowali przed sklepową półką, mają promocje. Idealnie pokrywają się marki wybierane z tymi, które były promowane. 
W powyższych analizach zaobserwować można, że producenci omawianego sektora stosują instrumenty promocji konsumenckiej, a działania te mają zasadniczy wpływ na decyzje zakupowe klientów. Wszyscy konsumenci dokonujący wyborów przed sklepową półką jako czynniki decydujące wskazują działania producentów z zakresu promocji konsumenckiej. Dodatkowo z analizy zebranych informacji wynika, iż marki wódek, których promocje konsumenci zauważyli, dokonując zakupu, są jednocześnie markami, które najczęściej zostawały zakupione w momencie, gdy decyzje zakupowe zapadały przed półką sklepową.

\section{PODSUMOWANIE}

Z całej komunikacji marketingowej najbardziej skuteczne są wszystkie instrumenty związane z bezpośrednim, publicznym dostępem do konsumenta, jak: reklama telewizyjna, radiowa, prasa, bilboardy i inne. Producenci wódek, biorąc udział w walce konkurencyjnej, ze względu na ograniczenia prawne nie mają dostępu do instrumentów reklamy publicznej. W tej sytuacji komunikacja skupia się na innych narzędziach. W omawianym sektorze w szczególności nasilają się promocje konsumenckie, a silna marka staje się głównym atutem konkurowania.

Przedstawione analizy nie pozostawiają wątpliwości, że główne czynniki wyboru zmieniają się wraz z ceną produktu. W przypadku wódek z najniższych przedziałów cenowych najczęściej decyduje dobra, niska cena. Natomiast główne czynniki wyboru w przypadku kategorii Mainstream, Premium, Top Premium to silna marka i działania promocyjne.

Analizując szczegółowo materiał badawczy pozyskany w wyniku przeprowadzonych badań, można z całą stanowczością stwierdzić, że w sektorze alkoholi wysokoprocentowych producenci korzystają z wszelkich możliwości działań promocyjnych, uwzględniając ustawę o wychowaniu w trzeźwości, całkowicie zakazującą reklamy publicznej. Konsumenci natomiast, dokonując wyboru alkoholi, w dużej mierze podejmują decyzje o zakupie pod wpływem promocji konsumenckich.

Podsumowując informacje, można również stwierdzić, że konsumenci nie tylko zauważają działania marketingowe wódek, ale też mają swoje preferencje odnośnie do ulubionych marek, co, jak wskazują badania, ma kluczowe znaczenie dla wyboru produktu. Można potwierdzić, że działania producentów z sektora alkoholi wysokoprocentowych kreują świadomość odbiorców, wpływają na decyzje zakupowe i aktywizują sprzedaż. 


\section{LITERATURA}

Alvarez B. A., Casielles R. V. (2005), Consumer evaluations of sales promotion: the effect on brand choice, „European Journal of Marketing”, vol. 39, Iss: 1/2.

Cummins J., Mullin R. (2005), Promocja sprzedazy, Helion, Gliwice.

Dhar S. K., Hoch S. J. (1996), Price discrimination using in-store merchandising, „Journal of Marketing", vol. 60, January.

Ehrenberg A. S. C., Hammond K., Goodhardt G. J. (1994), The after-effects of pricerelated consumer promotions, ,Journal of Advertising Research”, July-August.

Germain R., Iyer K. N. (2006), The interaction of internal and downstream integration and its association with performance, ,Journal of Business Logistics”, vol. 27/2.

Haffer M. (1998), Determinanty strategii nowego produktu polskich przedsiębiorstw przemysłowych, Wydawnictwo Uniwersytetu Mikołaja Kopernika, Toruń.

Kotler Ph. (1999), Marketing. Analiza, planowanie, wdrażanie i kontrola, Wydawnictwo Felberg SJA, Warszawa.

Kotler Ph. (2004), Odpowiada na pytania na temat marketingu, DW Rebis, Poznań.

Kozłowska A. (2011), Reklama, techniki perswazyjne, Oficyna Wydawnicza Szkoła Główna Handlowa, Warszawa.

Pawlak-Kołodziejska K. (2011), Komunikacja marketingowa, w: „Marketing. Podręcznik akademicki”, redaktor naukowy K. Andruszkiewicz, TNOiK Dom Organizatora, Toruń.

Mazurek-Łopacińska (2003), Zachowania nabywców i ich konsekwencje marketingowe, PWE, Warszawa.

Wiktor J. (2005), Promocja. System komunikacji przedsiębiorstwa z rynkiem, Wydawnictwo Naukowe PWN, Warszawa.

Wiśniewska A. (2005), Czynniki decydujące o wrażliwości konsumentów na markę, w: Instrumenty kształtowania wizerunku marki, red. A. Grzegorczyk, Wyższa Szkoła Promocji, Warszawa.

Witek-Hajduk M. K. (2011), Zarzadzanie silna marka, Wolters Kluwer Polska Sp. z o.o., Warszawa.

\section{CONSUMER PROMOTION IN A CASE OF PROHIBITION OF PUBLIC ADVERTISING}

A bstract: In today's economic reality, when a major economic force is competition main purpose of the business is customer satisfaction. The company needs to operate efficiently conduct large-scale promotional activities aimed at activation of the sale. The liquor industry a major hurdle in marketing communications are state restrictions prohibiting advertising. The article argues that in the face of a total ban on public advertising can still influence the purchasing decisions and activate sales.

K e y w o r d s : consumer promotion, communication, advertising. 